\title{
Wine quality, reputation, denominations: How cooperatives and private wineries compete?
}

\author{
Guenter H. Schamel
}

Free University of Bozen-Bolzano, School of Economics and Management, 39100 Bozen-Bolzano, Italy

\begin{abstract}
We analyze how cooperatives in Northern Italy (Alto Adige and Trentino) compete with private wineries regarding product quality and reputation, i.e. if firm organization affects wine quality and winery reputation. Moreover, we examine if cooperatives with deep roots in their local economy specialize in specific regional denomination rules (i.e. DOC, IGT). Compared to private wineries, cooperatives face additional challenges in order to raise wine quality, among them appropriate incentives that induce individual growers to supply high quality grapes (e.g. vineyard management and grape pricing schemes to lower yields). The quality reputation of a winery with consumers depends crucially on its winemaking skills. Wine regions differ with respect to climatic conditions and quality denomination rules. Assuming similar climatic conditions within wine regions as well as winemaking skills between firms, incentive schemes to induce individual growers to supply high quality grapes and quality denomination rules remain crucial determinants of wine quality and winery reputation when comparing different regions and firm organizational forms. The data set analyzed allows differentiating local cooperatives vs. private wineries and denotes retail prices, wine quality evaluations, indicators for winery reputation, and distinct denomination rules. We employ a hedonic pricing model in order to test the following hypothesis: First, wines produced by cooperatives suffer a significant reputation and/or wine quality discount relative to wines from private producers. Second, cooperatives and/or private wineries specialize in specific wine denominations for which they receive a price premium relative the competing organizational form. Our results are mixed. However, we reject the hypothesis that cooperatives suffer a reputation/wine quality discount relative to private producers for the Alto Adige wine region. Moreover, we find that regional cooperatives and private wineries specialize in specific wine denomination for which they receive a relative price premium (e.g. Alto Adige cooperatives specialize in DOC relative to private wineries in the region; private wineries in Trentino specialize in IGT denominated wines emphasizing their own brands). Our results indicate regional differences in terms of how cooperatives compete with private wineries with respect to wine quality and reputation. If cooperatives are able to implement incentive schemes to induce individual growers to raise grape quality, they may also gain a wine quality and reputation premium in the market. Specialization in local denomination rules allows private wineries and cooperatives to capture premium prices in different market segments.
\end{abstract}

\section{Introduction}

Privately owned firms and cooperatives represent ownership forms that can be found concurrently in many markets throughout the world [1-3]. Even in the U.S., cooperative enterprises are predominant in a number of industries including agriculture where they market as much as $1 / 3$ of total production [4]. Also in Europe, large share of agricultural produce is marketed by farmerowned cooperatives, but increasingly concerns are raised about their effectiveness and efficiency. In Europe, recent changes of the common agricultural policy imply that production and marketing of these products must meet specific requirements (improved quality management and marketing conditions, production efficiency, etc.) in order to comply with internal support regulations and to attain competitive positions within Europe as well as internationally.

We examine how cooperatives are able compete with private wineries regarding product quality and reputation. Product quality and reputation crucially affect product prices. Using a hedonic model, we test the hypothesis whether wines from private producers receive a reputation premium relative to cooperatively produced wines. We also hypothesize that wines from private wineries receive a price premium for wine quality relative to cooperatives. In addition, we examine if there is any strategic orientation towards specific quality denominations (IGT/DOC) and organizational form. Wine quality and reputation crucially affects market prices. Depending on the producer, considerable price differences exist even between otherwise very similar wines. We often observe that wine produced and marketed by a cooperative sells for less than a bottle of comparable quality from a private (non-cooperative) winery.

One explanation for this may be that cooperatives have a lower reputation for wine quality with consumers. Assuming similar wine winemaking and management abilities between different ownership forms, a cooperative's reputation for quality depends crucially on its individual 
growers supplying high quality grapes which in turn determine wine quality further downstream. In contrast, private wineries may face less uncertainty about grape qualities and in turn gain a higher reputation with final consumers.

Our empirical application examines the Alto Adige and Trentino wine regions in Northern Italy. In both regions, about $70 \%$ of the total wine production is marketed through cooperatives. This is more than twice as much as in Germany where only about $1 / 3$ of the total production is processed and marketed by cooperatives [5]. We observe that in Alto Adige more than in Trentino, wine cooperatives are characterized by modern production conditions utilizing cutting-edge vineyard management systems which require that growers are cutting back on grape tonnage at certain predefined times during the growing season in order to limit yields, thus raising grape quality and in turn wine quality further downstream [6]. Therefore, we examine if cooperatives in Alto Adige relative to the Trentino are able to lower the uncertainty about grape quality relative to private wineries such that the hypothesized price difference due to reputation and/or wine quality disappears. In addition, we study if there is any strategic orientation towards specific quality denominations (IGT/DOC). We expect that cooperatives deeply rooted within a territory may concentrate on DOC rules while private wineries may turn to a strategy of marketing and branding distinct IGT denominated wines.

\section{Literature review}

In fact very few studies have analyzed the relationship between ownership structure and product quality or reputation in general. Hoffmann [7] argues that despite an extensive literature on endogenous quality choice, the effects of different ownership structures have been largely overlooked in the literature. Since we have motivated the paper arguing that cooperatives face free rider problems in assuring high quality production, we limit our review of the existing literature to the case of cooperatives vs. private firms. Hoffmann [7] develops a game theoretical model to analyze cooperatives vs. investor owned firms (IOF) in a duopoly with simultaneous quality choice and price competition. With fixed cost of quality, IOFs charge higher prices and generate larger consumer surpluses than cooperatives by marketing higher qualities. With variable cost of quality, cooperatives have a structural cost advantage which is used to market larger quantities of higher quality product generating larger profits, larger consumer surplus and larger social welfare. Thus, firms can have a cost advantage due to ownership structure in addition to a quality advantage.

Pennerstorfer and Weiss [8] study the impact of decentralized decision making on product quality and conclude that cooperative members have an incentive to overproduce and free-ride on product quality. In their theoretical model, quality provision depends on how quality is aggregated and on the size of the cooperative. Empirically, they find that wines produced by Austrian cooperatives are of significantly lower quality. Hanf and Schweickert [9] analyze the conflict within wine cooperatives in Germany stemming from member orientation with a focus on quantity and customer (i.e. quality) orientation associated with a saturated and competitive market environment.

Our analysis extends previous research studying the pros and cons of cooperatives in terms of reaping economies of scale, transaction costs, market power in relation to downstream buyers, farm service and input provider, or product quality performance [9-13]. In this paper, we emphasize product quality and reputation effects caused by vertical collaboration between growers, winemakers and marketers in a cooperative enterprise.

Product quality and reputation crucially affect product prices. Economists often use hedonic models to empirically study price-quality and reputation effects $[8,12$, 14,16-18]. In his seminal paper, Rosen [15] posits that goods are valued for their utility-generating attributes. Consumers evaluate such attributes when making a purchasing decision. Competitive markets define implicit prices for these utility-generating attributes and the product price is the sum of implicit prices. Many studies have applied hedonic models defining implicit prices for wine quality and reputation attributes [8,12,16-18]. We examine the price-quality relationship in order to determine whether wines from private wineries receive a reputation and/or quality premium relative to cooperatives. In a previous study, Schamel [17] examines cooperatives in Germany and estimates that their wines suffer a reputation discount of about $10 \%$ relative to private wineries.

We contribute to the literature on reputation effects to explain product pricing. Shapiro [19] examines the effect of producer reputation on prices. Assuming competitive markets and imperfect consumer information, he shows that reputation yields a premium for highquality producers, which may be interpreted as revenue for investments in their reputation. In Tirole [20], collective reputation is the aggregate of individual producer reputations. With past and current actions affecting producer incentives, he shows that new producers may suffer from prior mistakes of older producers even after they have disappeared. For the global wine market, Schamel [18] develops a dynamic analysis of brand and regional reputation effects. In the following section, we set out the data and the empirical analysis to investigate whether cooperatives can compete with private wineries regarding product quality and reputation.

\section{Data and analysis}

We analyze a data set of wines evaluated in the annual Le Guide de l'Espresso (I vini d'Italia) for Alto Adige and Trentino in Northern Italy. We obtained three years of data published in the guide (2012-14 Editions). The data used in the estimation consists of 1265 wines from Alto Adige (377 from coops, 888 from private wineries) and 724 wines from Trentino (164 from coops, 560 from private wineries). We use a hedonic model to test whether cooperatives or private wineries can obtain higher implicit prices for reputation and product quality (Model 1) and to test for any strategic orientation towards specific quality denomination rules (Model 2).

The guide lists a range of applicable retail prices per bottle from which we use the lower bound for 
estimation purposes. The price information used in the estimation is submitted prior to the quality evaluation (i.e. the point rating by the expert tasters). Thus, it does not reflect any direct effects due to a favorable quality rating. The experts rate the wines according to a 20-point scale in half-point steps. The guide also provides a star-rating (between 0 and 3 ) for a winery's distinctiveness which can be regarded as a proxy for its reputation for wine quality.

Wine age at the time of evaluation ranged from 1-13 years. The wine guide differentiates wine color, sweet or desert wines, DOC and IGT designated wines, biologically or bio-dynamically produced wine, wine variety and special recommendations such as value for money and best regional buys. In addition, the guide allows to categorize whether a wine was produced by a local cooperative or not and includes production quantities (number of bottles produced).

Cooperatively produced wines, red vs. white wines, sweet wines, IGT vs. DOC designated wines, biolabeled wines and special recommendations are regular dummy variables. Wine variety is a categorical dummy differentiating seven varieties/wine types. Five varieties are in common for both regions (Gewürztraminer, Pinot Noir, Sauvignon Blanc, Riesling and Spumante). Lagrein and Schavia are specific for Alto Adige while Teroldego, Nosiola are specific for Trentino. As dependent variable we use the logarithm of the lower price bound $\log$ (price). We employ a log-linear function in our regression and estimate the following equation (Model 1):

$$
\begin{aligned}
& \log (\text { price })=\alpha+\beta_{1} \log (\text { points })+\beta_{2} \log (\text { Bottles }) \\
& +\beta_{3} \text { Age }+\beta_{4} \text { Stars }+\gamma_{1} \text { Red }+\gamma_{2} \text { Sweet }+\gamma_{3} \text { Bio } \\
& +\gamma_{4 j} \text { Variety }+\gamma_{5} \text { Coop }+\gamma_{6} I G T+\eta_{1} \text { ValueRec } \\
& +\eta_{2} \text { BuyRec }+\varepsilon
\end{aligned}
$$

where $\log$ (price) is the logarithm of the wine price, $\log$ (points) is the logarithm of the Gault Millau points (individual wine quality) and $\log$ (Bottles) is the logarithm of the production quantity, Coop is dummy variable as an indicator for the collective reputation of cooperatives while $\varepsilon$ is the error term with a zero mean and uniform variance. The regression equation stated above includes a number of variables to control for willingness to pay (price) effects due to:

- production quantity (scarcity effect implied by the number of bottles produced) $\beta_{2}$

- wine age (age in years at the time of evaluation) $\beta_{3}$

- star ranking (winery reputation for quality effect) $\beta_{4}$

- red vs. white wines (red wine premium) $\gamma_{1}$

- sweet or dessert wines (sweet wine premium) $\gamma_{2}$

- bio-labeled wines (organic-premium) $\gamma_{3}$

- wine variety (varietal premium) $\gamma_{4 j}$

- cooperative reputation effect $\gamma_{5}$

- IGT denomination effect $\gamma_{6}$

- value recommendation (ValueRec) $\eta_{1}$

- best buy recommendation (BuyRec) $\eta_{2}$.

Given its log-linear functional form, estimating the equation above yields price premiums and discounts relative to the contribution of the base category (nonsweet white DOC wine not bio-labeled and no distinct variety for the region). Finally, we tested both models and/or the residuals for normality (Jarque-Bera-Test) and heteroskedasticity (White-Test) and do not find any significant problems in the data. We also employed RESET tests which rejected other functional forms.

According to our expectation formulated in the introduction, consumers face more uncertainty regarding product quality and reputation for cooperatively produced wine. Accordingly, we formulate hypotheses A:

A. Relative to cooperatives, wines produced by private (non-cooperative) wineries receive

1 a reputation premium

2 a higher wine quality premium.

To test hypothesis A.1, we expect a significant but negative coefficient for the cooperative dummy variable which would indicate a negative collective reputation for cooperatives $\left(\gamma_{5}\right.$ coefficient for cooperatively produced wine). For hypothesis A.2, we expect a lower quality premium for wine from cooperatives. Thus, we split the sample into cooperative and private wineries and look for a significantly positive coefficient for the wine quality indicator $\log$ (points) that is higher in the cooperative subsample.

Our a priori expectation was that cooperatives in Alto Adige achieve a lower level of uncertainty about grape quality through vertical quality coordination and thus are in a better position to compete with private wineries in terms of wine quality and reputation. Thus, comparing the results for Alto Adige and Trentino, we would expect that cooperatives in Alto Adige outperform the cooperative in Trentino in terms of reputation and quality premiums.

In Model 2, we include interaction terms between DOC and IGT denominations and ownership structure, i.e. cooperative (Coop) vs. private (NonCoop) wineries. This is done to see if there is any strategic orientation towards specific quality denomination rules with respect to ownership structures. The second regression equation estimated looks as follows:

$$
\begin{aligned}
& \log (\text { price })=\alpha+\beta_{1} \log (\text { points })+\beta_{2} \log (\text { Bottles }) \\
& +\beta_{3} \text { Age }+\beta_{4} \text { Stars }+\gamma_{1} \text { Red }+\gamma_{2} \text { Sweet }+\gamma_{3} \text { Bio } \\
& +\gamma_{4 j} \text { Variety }+\gamma_{5} I G T^{*} \text { Coop }+\gamma_{6} I G T^{*} \text { NonCoop } \\
& +\gamma_{7} \text { DOC }{ }^{*} \text { NonCoop }+\eta_{1} \text { ValueRec } \\
& +\eta_{2} \text { BuyRec }+\varepsilon .
\end{aligned}
$$

Notice that in Model 2, the base category is a DOC wine produced by a cooperative (a non-sweet white wine that is not bio-labeled and not a differentiated variety within the region). The three remaining interaction terms between denomination rules and ownership structure are:

- IGT * Coop or IGT classified wine produced by cooperatives

- IGT * NonCoop or IGT classified wine produced by privately owned wineries

- DOC * NonCoop or DOC classified wine produced by privately owned wineries.

Our expected result formulated above was that cooperatives are deeply rooted in the local economy and thus specialize on local DOC denominated wines while 
Table 1. Results Model 1 for Alto Adige/AA: Dependent Variable: $\log ($ price).

\begin{tabular}{|c|c|c|c|c|c|c|c|c|c|}
\hline \multirow[b]{2}{*}{ Variable } & \multicolumn{3}{|c|}{ AA Wines } & \multicolumn{3}{|c|}{ AA Coops } & \multicolumn{3}{|c|}{ AA Non-Coops } \\
\hline & Coeff. & t-Stat. & Prob. & Coeff. & t-Stat. & Prob. & Coeff. & t-Stat. & Prob. \\
\hline Constant & $-4.46^{\ddagger}$ & -9.92 & 0 & $-4.53^{\ddagger}$ & -5.64 & 0 & $-3.93 \ddagger$ & -7.36 & 0 \\
\hline Log(Points) & $2.68^{\ddagger}$ & 17.0 & 0 & $2.75^{\ddagger}$ & 9.87 & 0 & $2.52^{\ddagger}$ & 13.4 & 0 \\
\hline Log(Bottles) & $-0.07 \ddagger$ & -8.62 & 0 & $-0.06^{\ddagger}$ & -4.014 & 0 & $-0.07 \ddagger$ & -6.9 & 0 \\
\hline Age & $0.11^{\ddagger}$ & 12.5 & 0 & $0.12 \ddagger$ & 11.5 & 0 & $0.11^{\ddagger}$ & 7.15 & 0 \\
\hline Stars & $0.07^{\ddagger}$ & 7.05 & 0 & 0.01 & 0.61 & 0.55 & $0.10^{\ddagger}$ & 8.54 & 0 \\
\hline Red Wine & $0.17 \ddagger$ & 5.79 & 0 & $0.26^{\ddagger}$ & 5.25 & 0 & $0.12 \ddagger$ & 2.90 & 0 \\
\hline Sweet Wine & $0.25^{\ddagger}$ & 6.36 & 0 & $0.26^{\ddagger}$ & 6.09 & 0 & $0.28^{\ddagger}$ & 3.97 & 0 \\
\hline Bio-Wine & $0.06^{*}$ & 1.65 & 0.10 & -0.17 & -1.39 & 0.17 & $0.07 *$ & 1.84 & 0.07 \\
\hline Coop & $0.11^{\ddagger}$ & 6.52 & 0 & - & - & - & - & - & - \\
\hline IGT & $0.11^{\ddagger}$ & 3.12 & 0 & -0.07 & -0.57 & 0.57 & $0.15^{\ddagger}$ & 4.25 & 0 \\
\hline Lagrein & -0.05 & -1.43 & 0.15 & -0.10 & -1.38 & 0.17 & 0.01 & 0.07 & 0.95 \\
\hline Schiava & $-0.28^{\ddagger}$ & -7.29 & 0 & $-0.40^{\ddagger}$ & -7.14 & 0 & $-0.22 \ddagger$ & -4.25 & 0 \\
\hline Gewürztr. & $0.24 \ddagger$ & 9.96 & 0 & $0.25 \ddagger$ & 7.04 & 0 & $0.25^{\ddagger}$ & 7.65 & 0 \\
\hline Pinot Nero & 0.05 & 1.25 & 0.21 & $-0.18^{\dagger}$ & -2.51 & 0.01 & $0.13 \ddagger$ & 2.80 & 0.01 \\
\hline Sauv. Blanc & $0.10^{\ddagger}$ & 4.52 & 0 & $0.13^{\ddagger}$ & 3.79 & 0 & $0.08^{\ddagger}$ & 2.86 & 0 \\
\hline Riesling & $0.11^{\ddagger}$ & 4.27 & 0 & 0.03 & 1.25 & 0.21 & $0.12 \ddagger$ & 4.01 & 0 \\
\hline Spumante & $0.14 *$ & 1.94 & 0.05 & & & & $0.15^{*}$ & 1.80 & 0.07 \\
\hline Money Value & $-0.36^{\ddagger}$ & -19.7 & 0 & $-0.36^{\ddagger}$ & -12.3 & 0 & $-0.34 \ddagger$ & -14.9 & 0 \\
\hline Best Buy & $-0.22 \ddagger$ & -7.60 & 0 & $-0.18^{\ddagger}$ & -3.52 & 0 & $-0.22 \ddagger$ & -6.84 & 0 \\
\hline F-statistic & & $135.0^{\ddagger}$ & 0 & & $67.1^{\ddagger}$ & 0 & & $86.5^{\ddagger}$ & 0 \\
\hline Wald F-stat. & & $165.3^{\ddagger}$ & 0 & & $134.6^{\ddagger}$ & 0 & & $98.0^{\ddagger}$ & 0 \\
\hline Adjusted $\mathrm{R}^{2}$ & & 0.66 & & & 0.74 & & & 0.62 & \\
\hline Observations & & 1265 & & & 377 & & & 888 & \\
\hline
\end{tabular}

Estimation Method: LS/White heteroskedasticity-consistent standard errors \& covariance. The symbols $\ddagger, \uparrow$, and $*$ denote significance at the $1 \%, 5 \%$, and $10 \%$ level, respectively.

private wineries specialize in IGT denominated wines, i.e. produce and market distinct wines outside local DOC rules. Accordingly, we formulate the hypotheses B:

B.1 Cooperatives receive a relative price premium for their DOC denominated wines.

B.2 Private (non-cooperative) wineries receive a relative price premium for their IGT denominated wines.

In order to confirm hypothesis B.1 using model 2, we expect a significant, but negative coefficient for the IGT*Coop interaction term $\left(\gamma_{5}\right)$. To confirm hypothesis B.2, we look for a significant, but positive coefficient for the IGT*NonCoop interaction term $\left(\gamma_{6}\right)$.

\section{Estimation results}

In presenting the results we focus on the variables specifically linked to the hypotheses presented. Thus, we will not discuss in great detail the estimated parameters associated with other control variables that are included in the hedonic model for completeness of the analysis.

Our estimation for Alto Adige/AA wines (Table 1) reveals a significantly positive coefficient for cooperative reputation. The estimate $(0.108)$ indicates that Alto Adige cooperatives receive a collective reputation premium (about 11\%) relative to their local privately owned competitors. This is even more remarkable given the fact that the model corrects for a wineries' quality reputation via the Stars variable.
On the contrary, our estimation for Trentino/TN Wines (Table 2) reveals a significant but negative reputation coefficient for the Trentino cooperatives (with a collective reputation discount of about $6 \%$ ). Thus, we cannot fully confirm hypothesis A.1. Wines coming from private (non-cooperative) producers do not receive a reputation premium relative to cooperative wines at least for the Alto Adige region. This mixed result confirms our observation stated above: cooperatives in Alto Adige (and in contrast to Trentino) are able to lower the uncertainty about grape quality relative to private wineries through vineyard yield management systems such that the hypothesized price difference due to reputation disappears.

Comparing the quality premium, i.e. the coefficients for $\log$ (points) in the cooperative and private (noncooperative) subsamples, we find that hypothesis A.2 is not confirmed for both Alto Adige and Trentino. This means that cooperatively produced wines are able to command a significant quality premium relative to private (non-cooperatively produced) wines (i.e. 2.748 vs. 2.515 comparing the $\log$ (points) coefficients for AA in Table 1 and 3.582 vs. 2.489 for $\mathrm{TN}$ in Table 2). Thus, we cannot confirm hypothesis A.2 for both Alto Adige and Trentino. Cooperatives in both regions are able to obtain a quality premium for their wines relative to private (non-cooperative) wineries. The regional difference between TN and AA with respect to hypothesis A.1 and A. 2 could mean that while the cooperatives in Trentino 
Table 2. Results Model 1 for Trentino/TN: Dependent Variable: $\log ($ price).

\begin{tabular}{|c|c|c|c|c|c|c|c|c|c|}
\hline \multirow[b]{2}{*}{ Variable } & \multicolumn{3}{|c|}{ TN Wines } & \multicolumn{3}{|c|}{ TN Coops } & \multicolumn{3}{|c|}{ TN Non-Coops } \\
\hline & Coeff. & t-Stat. & Prob. & Coeff. & t-Stat. & Prob. & Coeff. & $\mathrm{t}$-Stat. & Prob. \\
\hline Constant & $-5.20^{\ddagger}$ & -7.71 & 0 & $-7.05^{\ddagger}$ & -4.34 & 0 & $-4.20^{\ddagger}$ & -5.51 & 0 \\
\hline Log(Points) & $2.87 \ddagger$ & 11.64 & 0 & $3.58^{\ddagger}$ & 6.09 & 0 & $2.49 \ddagger$ & 8.95 & 0 \\
\hline $\log ($ Bottles $)$ & $-0.05^{\ddagger}$ & -5.60 & 0 & $-0.05^{\ddagger}$ & -3.64 & 0 & $-0.05^{\ddagger}$ & -4.70 & 0 \\
\hline Age & $0.09 \ddagger$ & 9.41 & 0 & $0.10^{\ddagger}$ & 5.30 & 0 & $0.10^{\ddagger}$ & 8.00 & 0 \\
\hline Stars & $0.14 \ddagger$ & 7.61 & 0 & $0.11^{\dagger}$ & 2.60 & 0.01 & $0.16^{\ddagger}$ & 7.37 & 0 \\
\hline Red Wine & -0.01 & -0.08 & 0.94 & $-0.16^{\ddagger}$ & -3.36 & 0 & 0.03 & 1.14 & 0.25 \\
\hline Sweet Wine & $0.22 \ddagger$ & 3.91 & 0 & -0.18 & -2.03 & 0.05 & $0.32 \ddagger$ & 5.77 & 0 \\
\hline Bio-Wine & -0.01 & -0.38 & 0.71 & $0.37 \ddagger$ & 8.59 & 0 & -0.04 & -1.04 & 0.30 \\
\hline Coop & $-0.06^{\ddagger}$ & -2.79 & 0.01 & - & - & - & - & - & - \\
\hline IGT & $0.07 \ddagger$ & 3.57 & 0 & 0.01 & 0.26 & 0.79 & $0.10^{\ddagger}$ & 4.08 & 0 \\
\hline Teroldego & $0.13^{\ddagger}$ & 3.01 & 0 & 0.07 & 0.80 & 0.43 & $0.18^{\ddagger}$ & 3.65 & 0 \\
\hline Schiava & $-0.09 \ddagger$ & -3.06 & 0 & $-0.10^{\dagger}$ & -2.30 & 0.02 & $-0.07 *$ & -1.95 & 0.05 \\
\hline Gewürztr. & $0.11 \ddagger$ & 3.12 & 0 & 0.00 & 0.02 & 0.98 & $-0.16^{\ddagger}$ & 4.71 & 0 \\
\hline Pinot Nero & $0.16^{\ddagger}$ & 4.18 & 0 & $0.18^{\ddagger}$ & 2.93 & 0 & $0.15^{\ddagger}$ & 3.31 & 0 \\
\hline Sauv. Blanc & -0.08 & -1.55 & 0.12 & -0.21 & 1.69 & 0.09 & -0.05 & -0.81 & 0.42 \\
\hline Riesling & 0.05 & 0.76 & 0.45 & $0.22^{\dagger}$ & 2.46 & 0.02 & 0.03 & 0.39 & 0.69 \\
\hline Spumante & $0.17 \ddagger$ & 3.55 & 0 & -0.08 & -0.88 & 0.38 & $0.21 \ddagger$ & 3.61 & 0 \\
\hline Money Value & $-0.36^{\ddagger}$ & -16.54 & 0 & $-0.41 \ddagger$ & -10.82 & 0 & $-0.33 \ddagger$ & -12.96 & 0 \\
\hline Best Buy & $-0.17 \ddagger$ & -5.30 & 0 & $-0.22 \ddagger$ & -3.31 & 0 & $-0.16^{\ddagger}$ & -4.47 & 0 \\
\hline F-statistic & & $109.4 \ddagger$ & 0 & & $26.3^{\ddagger}$ & 0 & & $90.9^{\ddagger}$ & 0 \\
\hline Wald F-stat. & & $117.8^{\ddagger}$ & 0 & & $84.4^{\ddagger}$ & 0 & & $93.2^{\ddagger}$ & 0 \\
\hline Adjusted $\mathrm{R}^{2}$ & & 0.73 & & & 0.73 & & & 0.732 & \\
\hline Observations & & 724 & & & 164 & & & 560 & \\
\hline
\end{tabular}

Estimation method: LS/White heteroskedasticity-consistent standard errors \& covariance. The symbols $\ddagger, \uparrow$, and $*$ denote significance at the $1 \%, 5 \%$, and $10 \%$ level, respectively.

may also have lowered the uncertainty about their grape quality supply relative to private wineries such that the wine quality premium for private wineries disappears, but this apparent success has not yet translated into a corresponding reputation effect with consumers which of course is a more long run effect. Thus, the competitive position for Trentino cooperatives is weaker relative to private wineries in Trentino.

The remaining results on the control variables listed in Tables 1 and 2 are mostly in line with other studies. For example, the storage effect (wine age) is relatively consistent across the sub-samples and ranges between $9 \%$ and $12 \%$. There is a red wine premium for Alto Adige but not for the Trentino region. It is interesting to note that bio-labeled wine has a positive coefficient at least for Alto Adige which is in contrast to other studies that have claimed the opposite [21].

Moreover, we note that the premium on IGT wine is positive for both Alto Adige (10.5\%) and Trentino (7.6\%). This result suggests that wines produced outside the local DOC rules command a price premium. Hence, the question is raised why DOC regulations, established to guarantee local quality wine production are not necessarily working in favor of receiving higher market prices. However, we notice that the coefficients for IGT wines are positive and significant in the non-cooperative sub-samples only for both regions. This would indicate that private (noncooperative) wineries may produce according to IGT classifications to sell off higher quality grapes and to market own-branded wines while avoiding DOC rules. We argue that this strategic orientation is confirmed by our results for model 2. Cooperatives get a collective reputation premium for focusing on DOC rules while their non-cooperative competitors use an IGT strategy emphasizing branding.

In Table 3, we list the results for model 2 including the interaction terms between IGT/DOC denominations and ownership structure (Coop/Non-Coop) for both Alto Adige and Trentino. Comparing IGT and DOC denominations, the estimated coefficients indicate that relative to a cooperative DOC wine, private (non-cooperative) wines receive a significant premium for their DOC wine in Trentino (the coefficient for DOC*NonCoop equals $+4.5 \%)$ but not so in Alto Adige $(-11.3 \%)$. Moreover, in Trentino, private (non-cooperative) wineries receive a significant premium for their IGT wine (the coefficient for IGT*NonCoop equals $+13.3 \%$ relative to cooperative DOC wines) while the coefficient is not significant for Alto Adige. The interaction term for IGT*Coop is not significant for both regions.

This means that we can only confirm hypothesis B.1 for Alto Adige and not Trentino. On the other hand, hypothesis B.2 is confirmed only for the Trentino but not for Alto Adige. This mixed result may be interpreted as follows: Cooperatives in both regions clearly specialize in DOC denominated wine which is expressed through 
Table 3. Results Model 2 for Alto Adige/AA and Trentino/TN: Dependent Variable: $\log ($ price).

\begin{tabular}{|c|c|c|c|c|c|c|c|}
\hline \multicolumn{4}{|c|}{ Alto Adige Wines } & \multicolumn{4}{|c|}{ Trentino Wines } \\
\hline Variable & Coeff. & t-Stat. & Prob. & Variable & Coeff. & t-Stat. & Prob. \\
\hline Constant & $-4.17^{\ddagger}$ & -9.26 & 0 & Constant & $-5.24 \ddagger$ & -7.75 & 0 \\
\hline Log(Points) & $2.66^{\ddagger}$ & 16.9 & 0 & Log(Points) & $2.87 \ddagger$ & 11.6 & 0 \\
\hline $\log$ (Bottles) & $-0.07 \ddagger$ & -8.61 & 0 & Log(Bottles) & $-0.05^{\ddagger}$ & -5.62 & 0 \\
\hline Age & $0.11 \ddagger$ & 12.4 & 0 & Age & $0.09 \ddagger$ & 9.44 & 0 \\
\hline Stars & $0.07 \ddagger$ & 7.02 & 0 & Stars & $0.14 \ddagger$ & 7.50 & 0 \\
\hline Red Wine & $0.17 \ddagger$ & 5.57 & 0 & Red Wine & -0.00 & -0.09 & 0.93 \\
\hline Sweet Wine & $0.26^{\ddagger}$ & 6.55 & 0 & Sweet Wine & $0.22^{\ddagger}$ & 3.88 & 0 \\
\hline Bio-Wine & $0.06^{*}$ & 1.71 & 0.09 & Bio-Wine & -0.02 & -0.51 & 0.61 \\
\hline IGT*NonCoop & 0.01 & 0.32 & 0.75 & IGT*NonCoop & $0.13^{\ddagger}$ & 4.81 & 0 \\
\hline IGT $*$ Coop & -0.11 & -0.95 & 0.34 & IGT*Coop & 0.02 & 0.29 & 0.78 \\
\hline DOC*NonCoop & $-0.11^{\ddagger}$ & -6.86 & 0 & DOC*NonCoop & $0.05 *$ & 1.86 & 0.06 \\
\hline Lagrein & -0.04 & -1.28 & 0.20 & Teroldego & $0.14 \ddagger$ & 3.14 & 0 \\
\hline Schavia & $-0.28^{\ddagger}$ & -7.18 & 0 & Nosiola & $-0.09 \ddagger$ & -3.04 & 0 \\
\hline Gewürztraminer & $0.23^{\ddagger}$ & 9.85 & 0 & Gewürztraminer & $0.12 \ddagger$ & 3.28 & 0 \\
\hline Pinot Nero & 0.06 & 1.37 & 0.17 & Pinot Nero & $0.16^{\ddagger}$ & 4.09 & 0 \\
\hline Sauv. Blanc & $0.10^{\ddagger}$ & 4.47 & 0 & Sauv. Blanc & -0.08 & -1.59 & 0.11 \\
\hline Riesling & $0.11^{\ddagger}$ & 4.29 & 0 & Riesling & 0.05 & 0.76 & 0.45 \\
\hline Spumante & $0.14 *$ & 1.93 & 0.05 & Spumante & $0.17 \ddagger$ & 3.65 & 0 \\
\hline Money Value & $-0.36^{\ddagger}$ & 19.7 & 0 & Money Value & $-0.36^{\ddagger}$ & 16.5 & 0 \\
\hline Best Buy & $-0.21^{\ddagger}$ & -7.69 & 0 & Best Buy & $-0.17 \ddagger$ & -5.3 & 0 \\
\hline F-statistic & & $128.5^{\ddagger}$ & 0 & F-statistic. & & $103.9^{\ddagger}$ & 0 \\
\hline Wald F-stat. & & $157.3^{\ddagger}$ & 0 & Wald F-stat. & & $111.6^{\ddagger}$ & 0 \\
\hline Adjusted $\mathrm{R}^{2}$ & & 0.657 & & Adjusted $\mathrm{R}^{2}$ & & 0.730 & \\
\hline Observations & & 1265 & & Observations & & 724 & \\
\hline
\end{tabular}

Estimation method: LS/White heteroskedasticity-consistent standard errors \& covariance. The symbols $\ddagger$, $\dagger$, and $*$ denote significance at the $1 \%, 5 \%$, and $10 \%$ level, respectively.

Table 4. Summary of Results.

\begin{tabular}{|c|c|c|c|}
\hline Estimation & Hypothesis & Alto Adige/AA & Trentino/TN \\
\hline \multirow{2}{*}{ Model 1} & A.1. & - & + \\
\cline { 2 - 4 } & A.2. & - & - \\
\hline \multirow{2}{*}{ Model 2} & B.1. & + & - \\
\cline { 2 - 4 } & B.2. & - & + \\
\hline
\end{tabular}

a price premium that they are able to receive for these wines in the market. On the other hand, private wineries are relatively weak competitors for cooperatives in Alto Adige (due to hypothesis A.1) and thus are not able to gain a price premium for their IGT denominated wine (hypothesis B.2).

In Alto Adige, it seems that cooperatives compete successfully focusing on DOC wines while private wineries at least to some degree avoid DOC rules to market and brand distinctly different IGT wines but according to our sample do not receive a price premium for these wines. On the other hand, in Trentino, private wineries receive a price premium both for DOC and IGT wines relative to their cooperative competitors. Our main results are summarized in Table 4.

\section{Discussion and conclusion}

In this paper, we provide empirical evidence illustrating how cooperative and private wineries compete regarding product quality and reputation. A cooperative's reputation for quality wine production depends crucially on the quality variation of its grape supply from individual growers. Thus, wine quality may be more uncertain further downstream. In contrast, a private (non-cooperative) winery is characterized by a high degree of control within the production chain and thus may face less uncertainty about wine quality further downstream. The resulting reputation and wine quality effects on market prices are analyzed in this paper.

Our results indicate that cooperative wineries in Alto Adige manage to organize their production decisions such that they are able to compete with private wineries both in terms of wine quality and reputation. Cooperatives in Trentino seem to also have lowered the uncertainty about their grape quality supply relative to private wineries such that the wine quality premium for private wineries disappears, but this apparent success has not yet translated into a corresponding long-run reputation effect with consumers. The relative competitive strength of Alto Adige cooperatives in terms of DOC wine production implies that private wineries are unable to command a price premium for their branded IGT wines. This is in contrast to neighboring Trentino where cooperatives are not able to command a long-run reputation premium for their DOC wines because of the relative competitive strength of private wineries, both in terms of DOC and IGT wine production. 
This paper shows that cooperatives are able to compete with private wineries regarding product quality and reputation. It can be accomplished by minimizing the downstream uncertainty about wine quality through strict management of the grape supply further upstream. The data shows that this can be observed in Alto Adige but only to a lesser degree in Trentino.

While this paper develops an interesting case of regional differences in terms of how successful cooperative enterprises may operate, it remains to be seen which case is more generally observed in other regions. While the Alto Adige case is very interesting from a cooperative organizational point of view, it may rather be the exception than the rule as suggested by the results from other regions reported in the literature $[8,9,12,17]$.

\section{References}

[1] Sexton, R. J., Lavoie, N., 2001, "Food Processing and Distribution: An Industrial Organization Approach." (Chapter 15, Volume 1B) in Handbook of Agricultural Economics, edited by Gardner B. and G. Rausser, Elsevier, North Holland, 863-932

[2] Hendrikse, G.W.J., 1998, Screening, Competition and the Choice of Marketing Cooperative as an Organizational Form, J. Agricultural Economics, 49(2): 202-217

[3] Hendrikse, G.W.J., 2007, On the Co-existence of Spot and Contract Markets: the Delivery Requirement as Contract Externality, European Review of Agricultural Economics, 34(2): 257-282

[4] Hansmann, H., 1996, The Ownership of Enterprise. Belknap Harvard

[5] DRV, 2012, "Entwicklung der Winzergenossen-schaften." Available at www.deutschewinzergenossenschaften.de/

[6] Schamel, G., Schubert, S. F., 2012. "A Dynamic Optimal Control Model of Crop Thinning." Paper presented at the 2012 Conference of the International Association of Agricultural Economists in Foz do Iguacu, Brazil

[7] Hoffmann, R., 2005, "Ownership Structure and Endogenous Quality Choice: Cooperatives versus Investor-Owned Firms", J. Agricultural \& Food Industrial Organization, 3(2), Article 8. Available at www . bepress.com/jafio/vol3/iss $2 /$ art 8
[8] Pennerstorfer, D., Weiss, C., 2013, "Product quality in the agri-food chain: Do cooperatives offer highquality wine?" European Review of Agricultural Economics, 40(1), pp. 143-162

[9] Hanf, J., Schweickert, E., 2014, "Cooperatives in the balance between retail and member interests: the challenges of the German cooperative sector." Journal of Wine Research, 25: 32-44

[10] Bonus, H., 1986, "The Cooperative Association as a Business Enterprise: A Study in the Economics of Transactions," J. Institutional and Theoretical Economics, 142(2): 310-339

[11] Albaek, S., Schultz, C., 1998, "On the relative advantage of cooperatives." Economics Letters, 59: 397-401

[12] Frick, B. 2004, "Does ownership matter? Empirical evidence from the German wine industry." Kyklos, 57: $357-386$

[13] Bogetoft, P. 2005, "An information economic rationale for cooperatives". European Review of Agricultural Economics, 32: 191-217

[14] Schamel, G., 2007, "Auction Markets for Specialty Food Products with Geographical Indications." Agricultural Economics, 37(2-3): 257-264

[15] Rosen, S., 1974, "Hedonic Prices and Implicit Markets: Product Differentiation in Pure Competition," $J$. Political Economy, 82: 34-55

[16] San Martin, G. Troncoso, J., and Brümmer, B., 2008, "Determinants of Argentinian Wine Prices in the U.S.," J. Wine Economics, 3(1), 72-84

[17] Schamel, G., 2009, "Can German Wine Cooperatives Compete on Quality?" Paper presented at the $27^{\text {th }}$ International Association of Agricultural Economists Conference, Beijing, China

[18] Schamel, G. 2009, "Dynamic Analysis of Brand and Regional Reputation: The Case of Wine." J. Wine Economics, 4(1): 62-80

[19] Shapiro, C., 1983, "Premiums for high quality products as Returns to reputations," Quarterly Journal of Economics, 98: 659-679

[20] Tirole, J., 1996. "A theory of collective reputations (with applications to the persistence of corruption and to firm quality)," Review of Economic Studies, 63: $1-22$

[21] Delmas, M., L. Grant, 2010, "Eco-Labeling Strategies and Price-Premium: The Wine Industry Puzzle," Business and Society, 49(4): 1-39 